\title{
An Informetric Analysis of Relationship between Open Access Presence and Ranking of African Universities
}

\author{
Ifeanyi J. Ezema* \\ Research Fellow, Department of Information Science, University of South Africa University \\ Librarian, Enugu State University of Science \& Technology, Enugu. \\ E-mail: ifeanyi.ezema@unn.edu.ng; Ifeanyi.ezema@esut.edu.ng
}

\section{Richard N.C Ugwuanyi}

Librarian, University of Nigeria, Nsukka.

E-mail: richard.ugwuanyi@unn.edu.ng

Received March 04, 2021; Accepted July 02, 2021

ISSN: $1735-188 X$

DOI: 10.14704/WEB/V18I2/WEB18304

\section{Abstract}

This study was conducted to determine the relationship between open access presence and ranking of African universities. It adopted descriptive informetric to examine open access presence of African countries using Directory of Open Access Repositories (DOAR) and Research Gate scores (RGs) of the universities. Data was also extracted from the Journal Consortium (an African university ranking organisation) for metrics on African university ranking. Data on African open access presence was correlated with university rankings. Findings reveal that only twenty-four countries in Africa have records in DOAR and Research gate. Four of the countries (South Africa, Egypt, Kenya and Nigeria) contribute more over $85 \%$ of open access records in Africa and the same produced $68 \%$ of the top 100 universities in Africa. The study found a highly significant positive but moderate correlation between open access presence and ranking of African universities. It concludes that African universities need to review their science policy in line with open access initiative to enhance the visibility and ranking of the university globally.

\section{Keywords}

Open Access, University Ranking, Informetric, Africa, Scientometrics, Research Evaluation.

\section{Introduction}

The beginning of the twenty-first century witnessed a turning point in the evaluation of performance of universities and other higher institutions across the globe when the Shanghai Jiao Tong University Institute of Higher Education (SJTUIHE) began the global 
university ranking and upon request from stakeholders from different parts of the world, it was published as Academic Ranking of World Universities (ARWU) in June 2003 (Liu \& Cheng 2005). Another university ranking body, the Times Higher Education Supplement (The United Kingdom's THE) commenced world universities ranking in 2004 (Marginson, 2007). Before this development, evaluation of performance of universities was subjective since individuals and groups adopted which ever suitable criteria for choice of universities. Often the choices were determined by perceived performance of the university in question in some disciplines. Though it is usually difficult to compare educational institutions on international perspectives due to differences in their establishment and geographical dimensions, the rankings provide a mechanism for university evaluation and by extension expose them to international competition. Consequently, the ranking has attracted greater interest among universities all over the world, their funding bodies and countries on their global performances. While university administrators try to improve research facilities and their research outputs, the funding bodies are raising questions on the outcomes of funds invested in the universities.

These two ranking bodies (Times Higher Education and Academic Ranking of World Universities) provided criteria and weights for the determination of the research performance of the universities since ranking on quality of the university will be a difficult task. These indicators are alumni and staff who have won Nobel Prizes and Fields Medals, high cited researchers in twenty-one broad subject areas, articles published in Nature and Science among others (Liu \& Cheng 2005, Marginson, 2007). The media interest in university rankings has resulted in policy changes among the universities to remain highly competitive in global knowledge economy. Studies on the political and economic implications of university ranking and how it is shaping public opinion has been well documented (European University Association 2012; Marope; Rauhvargers 2013; Daraio \& Bonaccorsi 2016). Apart from increasing prestige of the university, it also attracts international students and scholars and funding grants from international agencies even though these studies have observed that the rankings are usually misleading as a result of the criteria used.

Apart from these two major university ranking bodies, others are gradually springing up. There is the "Webometrics Ranking of World Universities" (http://www.webometrics.info/en) an initiative of the Cybermetrics Lab, a research group belonging to the Consejo Superior de Investigaciones Científicas (CSIC), the largest public research body in Spain. However, this ranking is without any metric for the universities and this does not clearly establish the bases for university performance. Others are Quacquarelli Symonds (QS) ranking of top Universities 
(http://www.topuniversities.com/qs-world-university-rankings) which relies mainly on international peer judgment; University Web Ranking \& Reviews (http://www.4icu.org/) and U-Multirank (http://www.umultirank.org/). There is also the CWTS Leiden ranking which uses bibliometric indicators in evaluation of 800 top world universities (http://www.leidenranking.com/). These ranking bodies hardly capture African universities and as a result African university ranking bodies such as Journal Consortium Africa University Ranking (http://ranking.journalsconsortium.org/) and The African Economics ranking (http://theafricaneconomist.com) emerged. Obviously these ranking bodies within and outside Africa depend largely on the web presence of the universities to gauge the performance of the universities. Open access publishing appears to provide web presence and ranking advantage since studies have demonstrated that open access publishing increases citations of research outputs (Noriss, Oppenheim, \& Rowland (2008).

Sadly, available literatures have reported slow response on the adoption of open access publishing in Africa (Ezema, 2011; Zaid \& Okiki, 2015) in relation to other regions like Europe and America. A recent Dakar declaration on open access publishing in Africa and the Global South by Council for the Development of Social Science Research in Africa (CODESRIA 2016) is a wakeup call for adoption of OA to key into the global knowledge economy. This study intends to determine whether open access presence correlates with the ranking of African universities. This is of great interest to African universities which have consistently ranked low by international ranking agencies. Specifically, the study intends to:

- Determine the open access presence of Africa universities in DOAR and Research Gate.

- Examine the geographical distribution of top ranked universities in Africa.

- Contrast the relationship between open access presence and ranking of universities.

\section{Literature Review}

Studies about university ranking are increasingly providing insight into the socio-economic and political dimensions of the rankings. Many have seen university ranking as a good mechanism for evaluation of university performance and Marginson (2007) observed that it is speedily changing the context of higher education globally. Apart from attracting more grants from funding agencies, the belief is that ranking reflects the quality of education from the universities and influences the entrants into universities (Broecke, 2015). Earlier study by Abbott \& Leslie (2004) found that highly ranked 
universities in the UK receive more students' applications. Consequently, many universities are reviewing policies and introducing new strategies to project themselves in the global landscape. Much as this has introduced a form of competition for the world universities, many have found some flaws in the criteria used for the ranking. For instance, in Marginson's (2007) report, the ARWU ranking proportion is as follow: 20\% each for citations to leading journals; articles in Science and Nature; number of Thomson/ISI high cite (HiCi) researchers; $30 \%$ to Nobel Prize winners and the remaining $10 \%$ is the total score divided by the staff population of the university. The ranking parameters are therefore skewed in favour of universities that are strong in the sciences and those with large number of Thomson/ISI HiCi researchers. According to Liu \& Cheng (2005), many notable universities that specialize in the Humanities and Social Sciences ranked low as result of imbalance in the research productivity in the subject areas. It is also important to note that several studies have accused Thomson Reuters of promoting and propagating flawed and biased bibliometric data (Hendrix, 2008; Ezema 2010) and by implication universities from the Europe and America would have ranking advantage over others considering the number of journals and authors indexed in Thomson Reuters' database. Similarly, Marginson (2007) has argued that the data base not only favour English language nations, but a large number of the researchers are from America. According to him "no less 3,614 of Thomson/ISI 'HiCi' researchers are in the United States." as against 224 in Germany, and 221 in Japan.

The Times Higher Education university ranking also has its own shortcomings. International opinion survey of academics constitutes $40 \%$ of the ranking scores and another $10 \%$ is allocated to the survey of global employers, then $5 \%$ each is for the international students and staff. The remaining is distributed to staff-student ratio (20\%) and staff citations in Thomson Reuter database (Marginson 2007). Apart from the earlier criticism about Thomson Reuter's database, these criteria have attracted a number of questions such as: what is the composition of the international academic survey which has a large chunk of $40 \%$ ? The same applies to the composition of the global employers. How much of the sample proportion come from developing areas particularly African countries?

For QS World University Rankings which relies more on international peer judgment, many have raised questions concerning the process of selecting the peer reviewers upon which judgments are made (Thelwall \& Kousha, 2015). The reality is that the questionnaire for the ranking had higher return rate from USA and UK from where the greater percentage of the respondents are drawn. It is also important to understand the proportion of distribution of the survey questionnaire - how many developing countries 
particularly in Africa, Asia and Southern America are captured through such survey. Such ranking skewed against developing countries often produce false results that hardly provide ranking for African universities. Consequently, Shahjahan, Ramirez \& Andreotti (2017) proposed a decolonization of global university ranking (GUR) which will afford equal opportunities to universities all over the world since according to them the ranking "narrows the imaginary of universities and human relationships in general, limiting the possibilities of knowledge and being." Much as ranking may provide evidences of good performances from university, it is important to be careful so that the major essence of the university is not lost. As has been pointed out, global university ranking attempts to confine world universities to compete in a largely and costly biased Eurocentric set of performance indicators where many universities in developing countries have very slim opportunities.

Perhaps, the development of open access publishing in 2003 (see the Budapest Open Access Initiative http://www.budapestopenaccessinitiative.org/read) could present greater opportunities for ranking of many world universities since it is believed that university ranking has relationship with research publication and citations which are enhanced through open access publications. Though, studies have continued to associate Africa with low research productivity (Ezema, 2010a; Nwagwu, 2013), the greatest challenges of African researchers are poor visibility and dissemination of their research reports (Ezema, 2013). This is because Africa research reports such as theses and dissertations, conference/seminar papers, inaugural lectures and articles in some local journals are poorly distributed for global visibility. It appears that the low visibility and of ranking of African universities are linked with inability to adopt open access publication.

Ezema \& Onyancha (2016b) also posit that open access presence improves citation counts and by extension ranking of universities. Ezema (2011) has earlier advocated for adoption of institutional repositories to ensure visibility of research publications in Africa. Consequently, many universities are increasingly adopting open access publishing through creation of institutional repositories and publishing in journals with open access presence.

The influence of open access publishing on the visibility and global ranking of universities has also been underscored by Ebrahim (2015). According to him, publishing papers in high impact journals usually does not provide the necessary visibility and citations. This has been demonstrated by Noorden, Maher \& Nuzzo (2014) in their report that $43 \%$ of papers indexed in Thomson Reuters's ISI has never received any citation. The study of Onyancha (2015) has also demonstrated the relationship between open access 
publishing and global ranking in his investigation of ResearchGate - a social media platform which allows researchers to self-archive their publications for global visibility and access. The study found a positive correlation between publications in open access outlet and ranking of universities. Though, there has been some criticism about the ResearchGate metrics, many researchers (particularly in developing countries) have profiles in this academic social media platform (Kraker, Jordan \& Lex 2015). It has been found to be one of the most popular social media among researchers globally (Haustein, Peters, Bar-Ilan, et al., 2013). Based on the popularity of this social media platform, other studies have been conducted on the relationship between ResearchGate metrics and other traditional research evaluation metrics. Thelwall \& Kousha (2015) investigated whether ResearchGate data relate with existing academic hierarchies and the potential benefits of individual countries and found that rankings based on ResearchGate statistics correlate moderately with other rankings of academic institutions and many countries are already archiving their publication using the platform.

\section{Materials and Methods}

The design of this study was descriptive informetrics which Diodato (1994:15) refers to as "the collection of descriptive information about documents to provide bodies responsible for the production and transmission of information; form of transmission; medium of communication; nature of information conveyed and geographical origin." Data used for the study was extracted from three sources, namely; Directory of Open Access Repositories (DOAR) http://www.opendoar.org/, Research Gate (https://www.researchgate.net/home) and Journal Consortium (http://ranking.journalsconsortium.org/unirankings) which provides metrics for the ranking based on research publications \& citations, internet/web presence and impact influence. There is however no other explanation on how the metrics were computed apart from "the ranking is based on research publications and citations from the five years as well as visibility on the internet." Data on open access presence was extracted from DOAR and Research Gate; while data on Africa university ranking indicators was extracted from Journal Consortium website (an African developed ranking body). Though there are many ranking bodies, Journal Consortium was chosen for the study because of its comprehensiveness in ranking African universities with required metrics based on the evaluation.

Other ranking body such as Webometric ranking of African universities has no known metric for the ranking, while Time Higher Education and QS Rankings could only provide rankings for very few universities in Africa. Although Webometric ranking listed 1497 
institutions in Africa, many of them are polytechnics and colleges. Therefore, only 100 best universities were purposively sampled for the study since many funding groups are usually interested in the first 100 universities. Therefore, the criterion used for the selection of the universities is on their ranking performance. As pointed in the literature, ranking bodies usually have language biases which may result in exclusion of some good universities which has African or Arabic languages as a medium of instruction. This may therefore affect the generalizability of the findings. Data was extracted from December 5 - 102019 and exported into Microsoft excel for computation. In DOAR, data for each country was extracted by typing the country name in the search field of the directory and through the process the number of repositories and records were generated.

The same process was used to extract data from ResearchGate. Founded in 2008 by Dr. Ijad Madisch, Dr. Sören Hofmayer, and Horst Fickenscher, ResearchGate currently has over 13 million members. Data was obtained from Research gate because it is one of the most popular academic social media sites that encourages self-archiving of open access full text publications. It also provides RG scores (research metric) for individual authors and universities which helps "measure and leverage your standing within the scientific community" (Research Gate 2017). RG scores are obtained by the researchers' contributions (number of papers archived including questions and answers), interactions (communication with scientific community particularly the reputation of researchers that interact with the authors) and reputation (citations and number of reads received on the platform) on the Research Gate platform. Unlike metrics, the RG Score focuses on the researcher, but the scores for researchers accumulate to the researchers' affiliations. For the ranking of African universities, data was extracted the same period. For the analysis of university ranking, only countries that have contributed top hundred universities were used. The impact influence and web presence of the 100 top universities in Africa were correlated with their open access records in DOAR and Research Gate to determine whether there is any significant relationship. The top 100 universities in Africa with their impact influence and countries of origin are provided as appendix 1. To avoid systematic biases, data from DOAJ was normalized using z-score which describes the location of a value within the distribution; and mathematically calculated as: $\mathrm{z}-\frac{\mathrm{X}-\overline{\mathrm{x}}}{\mathrm{SD}}$ where $z=z$-score, $x=$ number of records in DOAR; $\bar{X}=$ mean and $S D=$ standard deviation.

\section{Results}

The findings of the study are presented in this section in line with objectives, namely the determination of open access presence of African universities, geographical distribution of 
top ranked universities in Africa with their open access presence and the correlation between open access presence and university rankings.

Table 1 Top twenty African universities with their open access indicators

\begin{tabular}{|c|c|c|c|c|c|c|c|c|c|c|c|}
\hline Rank & Universities & $\begin{array}{l}\text { Research } \\
\text { Publications } \\
\text { \& Citations }\end{array}$ & $\%$ & $\begin{array}{l}\text { Internet/Web } \\
\text { Presence }\end{array}$ & $\%$ & $\begin{array}{l}\text { RG } \\
\text { Scores }\end{array}$ & $\%$ & DOAR & $\%$ & $\begin{array}{l}\text { Total } \\
\text { impact } \\
\text { 'Influence } \\
\text { Score }\end{array}$ & $\%$ \\
\hline 1 & $\begin{array}{l}\text { University of Cape } \\
\text { Town }\end{array}$ & 40.89 & 5.61 & 4.13 & 6.32 & 29350.86 & 12.04 & 20272 & 3.20 & 45.02 & 5.67 \\
\hline 2 & Cairo University & 39.75 & 5.45 & 3.68 & 5.63 & 25849.69 & 10.61 & 0 & 0.00 & 43.43 & 5.47 \\
\hline 3 & University of Pretoria & 39.66 & 5.44 & 3.69 & 5.65 & 21631.05 & 8.88 & 48892 & 7.73 & 43.35 & 5.46 \\
\hline 4 & University of Nairobi & 38.8 & 5.32 & 4.01 & 6.14 & 6212.2 & 2.55 & 78400 & 12.39 & 42.81 & 5.39 \\
\hline 5 & $\begin{array}{l}\text { University of South } \\
\text { Africa }\end{array}$ & 37.72 & 5.17 & 4.6 & 7.04 & 5369 & 2.20 & 15617 & 2.47 & 42.32 & 5.33 \\
\hline 6 & $\begin{array}{l}\text { University of the } \\
\text { Witwatersrand }\end{array}$ & 39.07 & 5.36 & 3.14 & 4.80 & 22383.3 & 9.19 & 13256 & 2.09 & 42.2 & 5.31 \\
\hline 7 & $\begin{array}{l}\text { Stellenbosch } \\
\text { University }\end{array}$ & 39.32 & 5.39 & 2.83 & 4.33 & 22407.18 & 9.20 & 60480 & 9.56 & 42.16 & 5.31 \\
\hline 8 & University of Ibadan & 38.45 & 5.27 & 2.77 & 4.24 & 8304.7 & 3.41 & 0 & 0.00 & 41.22 & 5.19 \\
\hline 9 & $\begin{array}{l}\text { University of } \\
\text { Kwazulu Natal }\end{array}$ & 38.36 & 5.26 & 2.77 & 4.24 & 19057.93 & 7.82 & 11779 & 1.86 & 41.13 & 5.18 \\
\hline 10 & $\begin{array}{l}\text { Ain Shams } \\
\text { University }\end{array}$ & 37.54 & 5.15 & 3.01 & 4.61 & 15879.6 & 6.52 & 0 & 0.00 & 40.54 & 5.10 \\
\hline 11 & $\begin{array}{l}\text { University of } \\
\text { Johannesburg }\end{array}$ & 36.97 & 5.07 & 3.09 & 4.73 & 7651.6 & 3.14 & 18659 & 2.95 & 40.05 & 5.04 \\
\hline 12 & Makerere University & 36.67 & 5.03 & 3.35 & 5.13 & 8867.51 & 3.64 & 513 & 0.08 & 40.03 & 5.04 \\
\hline 13 & University of Nigeria & 35.98 & 4.93 & 3.98 & 6.09 & 8207.35 & 3.37 & 25667 & 4.06 & 39.96 & 5.03 \\
\hline 14 & University of Ghana & 33.95 & 4.66 & 3.88 & 5.94 & 6063.59 & 2.49 & 6795 & 1.07 & 37.83 & 4.76 \\
\hline 15 & $\begin{array}{l}\text { Addis Ababa } \\
\text { University }\end{array}$ & 33.49 & 4.59 & 2.64 & 4.04 & 5207.84 & 2.14 & 9098 & 1.44 & 36.13 & 4.55 \\
\hline 16 & Rhodes University & 33.14 & 4.54 & 2.71 & 4.15 & 5067.37 & 2.08 & 4096 & 0.65 & 35.85 & 4.51 \\
\hline 17 & $\begin{array}{l}\text { Alexandria } \\
\text { University }\end{array}$ & 32.9 & 4.51 & 2.72 & 4.16 & 12019.22 & 4.93 & 301647 & 47.67 & 35.62 & 4.48 \\
\hline 18 & $\begin{array}{l}\text { Ahmadu Bello } \\
\text { University }\end{array}$ & 32.9 & 4.51 & 2.66 & 4.07 & 3366.49 & 1.38 & 14368 & 2.27 & 35.57 & 4.48 \\
\hline 19 & $\begin{array}{l}\text { University of the } \\
\text { Western Cape }\end{array}$ & 31.8 & 4.36 & 3.02 & 4.62 & 6563.76 & 2.69 & 2595 & 0.41 & 34.82 & 4.38 \\
\hline \multirow[t]{2}{*}{20} & University of Lagos & 31.8 & 4.36 & 2.68 & 4.10 & 4223.08 & 1.73 & 619 & 0.10 & 34.48 & 4.34 \\
\hline & Total & 729.16 & 100 & 65.36 & 100 & 243683.3 & 100 & 632753 & 100 & 794.52 & 100 \\
\hline
\end{tabular}

Table 1 is the rank list of top twenty universities in Africa with their open access presence in terms of research gate scores (RGS) and records in directory of open access repositories (DOAR). South Africa has seven of the top ten universities which is a reflection of open access presence of the country as shown in table 2 . A close observation shows that the University of Cape Town which ranks first has the highest RGS of $12.04 \%$ followed by Cairo University with $10.61 \%$ and also $2^{\text {nd }}$ in the ranking of African universities. However, two universities (Cairo University and University of Ibadan) among the top ten have no records in DOAR. Could this imply that their ranking was enhanced mainly by RGS and web presence tracked by the ranking agency? A related development could be seen in University of Nairobi ( $4^{\text {th }}$ in the ranking) with only $2.55 \%$ in RGS, but high number of records in DOAR (12.39\%). It is however surprising that Alexendria University ( $17^{\text {th }}$ in the ranking) has the highest records in DOAR, and impressing RGS (4.93) but could not appear among the top ten universities. 


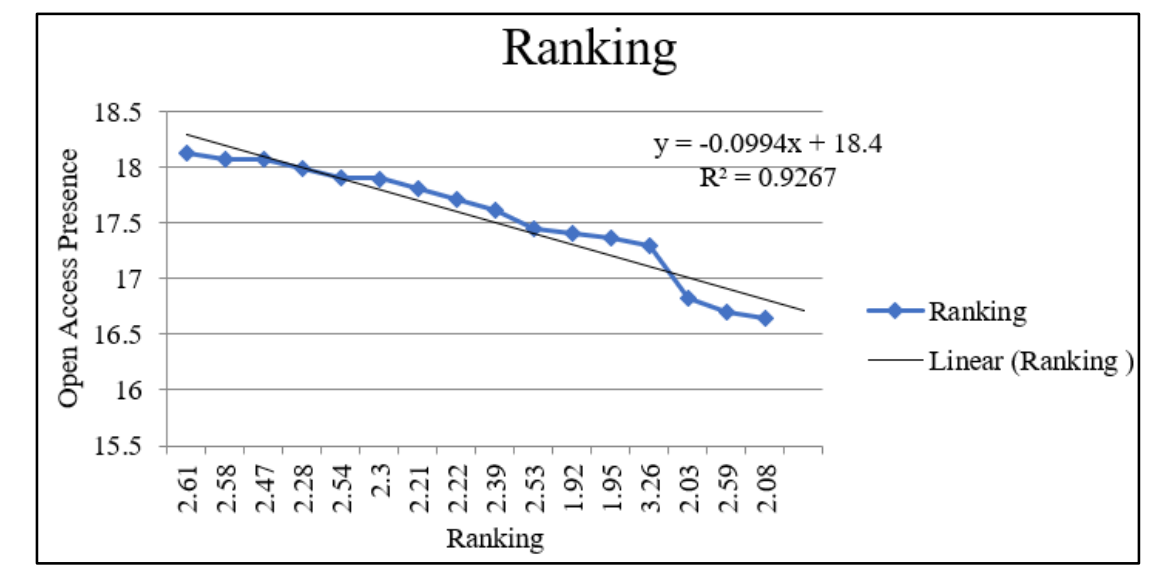

Figure 1 Open access presence and universities with low ranking

Figure 1 is trend line showing that universities with low open access presence have low ranking. In other words, as the open access presence of the universities decreases; the ranking continues to come down. The last 15 ranked universities (R85 - R100) maintain low ranking as the open access presence decreases from 18.13 to 16.64 .

Table 2 Geographical Spread of Top Hundred Universities in Africa and Country's Open Access Presence

\begin{tabular}{|c|c|c|c|c|c|c|c|c|c|c|c|c|}
\hline Rank & Countries & $\begin{array}{l}\text { Top } \\
10\end{array}$ & $\begin{array}{l}\text { Top } \\
20\end{array}$ & $\begin{array}{l}\text { Top } \\
50\end{array}$ & $\begin{array}{l}\text { Top } \\
100\end{array}$ & $\begin{array}{l}\text { Weighted } \\
\text { impact } \\
\text { influence }\end{array}$ & $\%$ & $\begin{array}{l}\text { No of } \\
\text { records } \\
\text { in } \\
\text { DOAR }\end{array}$ & Normalized & $\%$ & $\begin{array}{l}\text { Research } \\
\text { gate Score }\end{array}$ & $\%$ \\
\hline 1 & South Africa & 6 & 9 & 14 & 19 & 615.06 & 23.79 & 227360 & 28.9 & 28.62 & 174293.93 & 36.11 \\
\hline 2 & Nigeria & 1 & 4 & 12 & 28 & 709.77 & 27.45 & 46500 & 2.0 & 5.85 & 63412.49 & 13.14 \\
\hline 3 & Egypt & 2 & 3 & 10 & 17 & 473.08 & 18.30 & 317772 & 42.3 & 40.00 & 127886.78 & 26.49 \\
\hline 4 & Kenya & 1 & 1 & 3 & 5 & 145.98 & 5.65 & 116435 & 12.4 & 14.65 & 12041.72 & 2.49 \\
\hline 5 & Ghana & & 1 & 2 & 3 & 92.28 & 3.57 & 11817 & -3.2 & 1.49 & 11873.59 & 2.46 \\
\hline 6 & Uganda & & 1 & 1 & 1 & 40.03 & 1.55 & 931 & -4.8 & 0.12 & 8867.51 & 1.84 \\
\hline 7 & Ethiopia & & 1 & 1 & 4 & 36.13 & 1.40 & 4231 & -4.3 & 0.53 & 9445.16 & 1.96 \\
\hline 8 & Algeria & & & 1 & 3 & 29.63 & 1.15 & 29802 & -0.5 & 3.75 & 4034.28 & 0.84 \\
\hline 9 & Sudan & & & 1 & 2 & 52.77 & 2.04 & 17804 & -2.3 & 2.24 & 4156.90 & 0.86 \\
\hline 10 & Zimbabwe & & & 1 & 1 & 29.47 & 1.14 & 2408 & -4.6 & 0.30 & 3150.33 & 0.65 \\
\hline 11 & Botswana & & & 1 & 1 & 28.72 & 1.11 & 1044 & -4.8 & 0.13 & 3408.04 & 0.71 \\
\hline 12 & Zambia & & & 1 & 1 & 28.39 & 1.10 & 3395 & -4.4 & 0.43 & 2329.19 & 0.48 \\
\hline 13 & Morocco & & & 1 & 2 & 44.15 & 1.71 & 4602 & -4.2 & 0.58 & 8668.18 & 1.80 \\
\hline 14 & Tanzania & & & 1 & 2 & 47.93 & 1.85 & 5016 & -4.2 & 0.63 & 4959.65 & 1.03 \\
\hline 15 & Tunisia & & & & 2 & 35.96 & 1.39 & 687 & -4.8 & 0.09 & 19863.98 & 4.11 \\
\hline 16 & Benin & & & & 1 & 17.62 & 0.68 & 0 & -4.9 & 0.00 & 2576.71 & 0.53 \\
\hline 17 & Malawi & & & & 1 & 22.42 & 0.87 & 0 & -4.9 & 0.00 & 2010.40 & 0.42 \\
\hline 18 & Mauritius & & & & 1 & 18.31 & 0.71 & 0 & -4.9 & 0.00 & 1799.88 & 0.37 \\
\hline 19 & Mozambique & & & & 1 & 18.20 & 0.70 & 3103 & -4.5 & 0.39 & 1296.88 & 0.27 \\
\hline 20 & Namibia & & & & 1 & 22.53 & 0.87 & 1207 & -4.7 & 0.15 & 1398.05 & 0.29 \\
\hline 21 & Reunion & & & & 1 & 19.40 & 0.75 & 0 & -4.9 & 0.00 & 3757.30 & 0.78 \\
\hline 22 & Senegal & & & & 1 & 21.33 & 0.82 & 400 & -4.9 & 0.05 & 4113.38 & 0.85 \\
\hline 23 & Burkina Faso & & & & 1 & 17.45 & 0.67 & 0 & -4.9 & 0.00 & 1807.80 & 0.37 \\
\hline \multirow[t]{2}{*}{24} & Cameroun & & & & 1 & 19.18 & 0.74 & 0 & -4.9 & 0.00 & 5574.45 & 1.15 \\
\hline & Total & 10 & 20 & 50 & 100 & 2585.79 & 100 & 794,514 & & 100 & 482726.58 & 100 \\
\hline
\end{tabular}


As can be seen in table 2, only 24 countries produced the 100 top universities in Africa with South Africa, Nigeria and Egypt producing 19, 28 and 17 respectively. South Africa produced six of the top 10 universities with Egypt producing 2 and one each for Nigeria and Kenya. The first twenty universities are from South Africa (9), Nigeria (4), Egypt (3), and one each for Kenya, Ghana, Uganda and Ethiopia; while top fifty universities are from 14 countries with South Africa producing the highest (14), Nigeria (12), Egypt (10), Kenya (3), Ghana (2) and others one each. Although Nigeria has the highest weighted impact influence, the average is low because of the number of universities. South Africa, Egypt and Kenya followed Nigeria in that order in weighted impact influence.

Table 3 Correlation Matrix

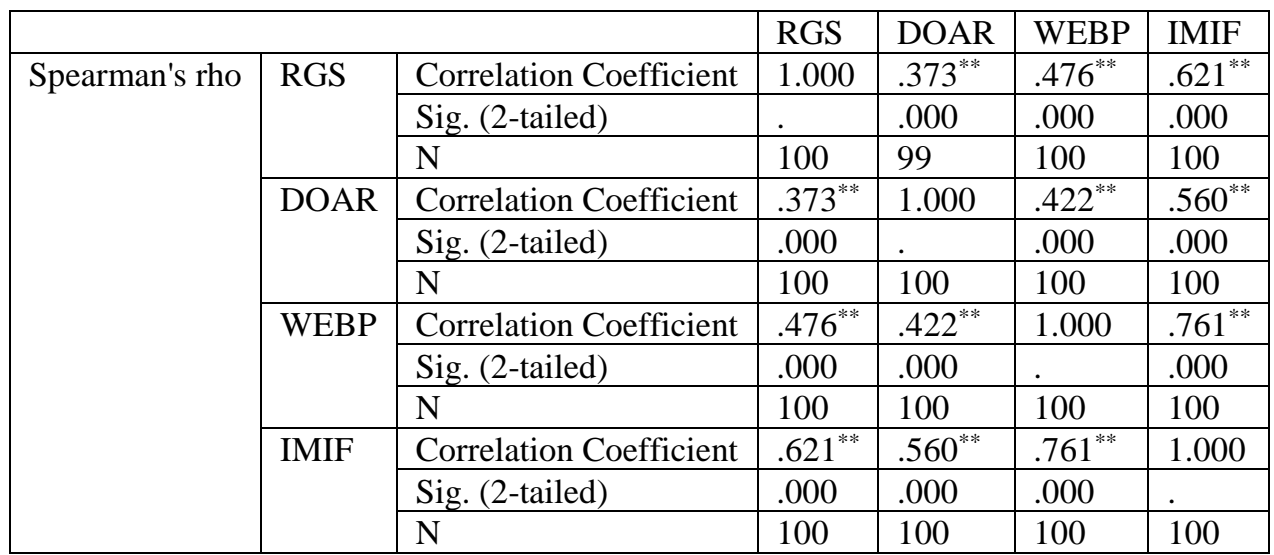

**. Correlation is significant at the 0.01 level (2-tailed).

KEY: RGS = Research gate scores; DOAR = Directory of open access repositories; WEBP; web presence; IMIF = Impact Influence

The result of the correlation between open access presence (research gate scores - RGS and directory of open access repositories - DOAR) and university ranking as reflected by web presence (WEBP) and impact influence (IMIF) is presented in table 4. Interpretation of correlation coefficient (r) was determined using Rumsey (2010) which provides that ' $r$ ' value close to 0.30 is weak; 0.50 , moderate; 0.70 , strong and 1 perfect correlation. The result shows that RGS has a highly significant positive, but weak correlation with WEBP $(\mathrm{r}=0.476, \mathrm{p}<0.05)$; and a highly significant positive but moderate correlation with IMIF $(\mathrm{r}=0.621, \mathrm{p}<0.05)$. Similarly, DOAR also has a highly significant positive but weak correlation with WEBP $(\mathrm{r}=0.422, \mathrm{p}<0.05)$, but a highly significant positive but moderate correlation with IMIF $(\mathrm{r}=0.560, \mathrm{p}<0.05)$. However, WEBP has a highly significant, positive and strong correlation with $\operatorname{IMIF}(r=0.761, \mathrm{p}<0.05)$. This implies that open access presence is correlated with ranking of African universities but the correlation coefficient is basically moderate. 


\section{Discussions}

Africa's low presence in the global open access directories is an indication of lack of visibility of its research outputs which is likely to account for poor ranking of African universities when compared with others across the globe. African has over fifty countries, but only 24 have open access presence among the top hundred. It appears that low open access presence is linked with poorly ranked universities as can be observed in the appendix provided. Could it be that many of the countries with low open access presence are yet to adopt open access archiving of their research or they lack the resources for adoption of open access repositories? This has been the concern of Zaid \& Okiki (2015) on the slow adoption of open access repositories in Africa universities. The development of institutional repositories provides a good outlet for the developing countries to provide wider visibility to their research outputs particularly if the repositories are hosted by major international repository directories such Directory of Open Access Repositories (DOAR) and Registry of Open Access Repositories (ROAR). However, as has been noted by Ezema (2011) and Nwagwu (2013) a lot of infrastructural challenges and poor funding of research limit the capacity of many African universities. The poor development of digital infrastructure in Africa to a large extent limits the research communication potentials of many universities in the continent. It is however, interesting that some universities in few African countries such as South Africa, Egypt, Kenya and Nigeria have been able to key into open access repositories for the visibility of their universities, but it is essential to note that Nigeria and Egypt are yet to exploit their full potentials in open access presence considering their population and number of universities in the countries. Nigeria for instance has 141 universities (National University Commission, 2015) which would produce at least the corresponding number of repositories and more records in Research Gate. Egypt with forty universities (see: http://www.rdi.eg.net/) would contribute corresponding number of repositories instead of 5 and more Research gate scores. It is also important to observe the lead which South Africa, Nigeria, Egypt and Kenya has continued to maintain for a long time in research outputs and other bibliometric indicators as reported in earlier literature such as Ezema, (2010b), Fox and Hanlon (2015). The universities in these countries have also continued to maintain the lead in open access presence of universities in Africa as has been reported by Ezema \& Onyancha (2016a). Therefore, until African universities begin to show interest in open access publishing, it will really be difficult to promote visibility and access of research productivity from Africa. Universities in Africa need to use the recent Dakar Declaration on Open Access Publishing for Africa and the Global South as a framework to initiate open access publishing particularly the development of institutional repositories for globalization of research outputs of African universities. 
The geographical distribution of top ranked universities in Africa shows that the leading countries in open access presence also has majority of the 100 top ranked universities. Though Nigeria has more number of universities in the list of 100 top universities in Africa, South Africa has six of the best 10 universities, almost half of the best 20 universities and 14 of the best 50 universities which are indications of high performance. It is also worthy of note that four countries with greater open access presence (Nigeria, South Africa, Egypt and Kenya) have almost $70 \%$ of the 100 best universities in Africa and the remaining $31 \%$ are distributed across other 20 African countries - an indication that open access presence is likely to influence ranking of universities as has been reported in extant literature (see Onyancha 2015).

African's total RGs is 480798.82 about $56.8 \%$ of 846296 the RGs of Harvard University. One begins to wonder why so many African universities are yet to adopt sharing their research outputs using this medium. Does this relate to earlier studies that have demonstrated low research outputs from Africa (see Ezema, 2010a; Nwagwu, 2013) or is it lack of awarness of open access publishing as has been reported in extanct literature (see Utulu \& Bolarinwa, 2009). The low RG scores from African universities could also be attributed to the language of Research gate which is generally English. Many university researchers who would ordinarily archive their publications in the platform may not have the required language proficiency and the universities may not have English language experts that would be of assistance and similar scenario is also observed in Directory of Open Access Repository (DOAR).

The rankings of African universities provide data related with the open access presence of the countries as six of the top ten universities are from South Africa and two from Egypt. Extant literature has associated open access to citation advantage which is a critical indicator for university ranking (Ebrahim 2015) and this often translate to increased performance during ranking which was demonstrated in the study by Onyancha (2011) using social media platform - Research gate. It is therefore, not surprising that universities with greater open access presence performed better than others in the rankings of African universities. Even though two of the top ten universities have no record in DOAR, it is likely that their rankings could have been enhanced with more records in DOAR. This therefore, points to the interest many universities show in enhancing visibility and increasing the bibliometric indicators (publication outputs and citations) as has been observed by Thelwall \& Kousha (2015). Consequently, this finding should serve as a wake-up call for African universities to key into the open access framework through 
the development of repositories for international visibility of their research output which Ezema (2011) had earlier proposed.

The correlation tests conducted showed highly positive relationship between open access presence and ranking of African university which corroborates the study of Onyancha (2011). A close observation of rankings of African universities in major international ranking bodies such as Academic Ranking of World Universities (ARWU), Times Higher Education, QS University Ranking of top Universities and Webometrics Ranking of World Universities indicates very low ranking of African universities. Apart from South African universities others are hardly ranked owing to poor visibility of these universities and this trend can be reversed if African universities would key into the opportunities provided by open access movement. Even with skewed ranking indicators from the Eurocentric ranking bodies (Marginson 2007), the adoption of open access repositories may likely create improved ranking advantages to universities in Africa. This development calls for the review science policies of African universities in line with open access framework. This may not be easy because it requires huge funding and government support so as to create good research environment in the universities such as capacity building and provision of enabling and sustainable ICT infrastructure. Unfortunately, many African governments continue to pay lip services in educational development and good research culture in particular. Nwagwu (2013) has rightly observed that some government agencies in charge of education and research lack the policy frame work for open access movement in Africa. This development creates doubts in the capacity of African universities to sustain higher education and training and attract foreign students and schoalrs which has resulted in huge capital flights to European and American universities from Africa.

\section{Conclusion/Recommendations}

Although ranking of world universities is a twenty-first century development, it has attracted attention of all the stakeholders and scholarly communinity all over the world. Given the ranking criteria, it has generated a lot of criticisms which supposedly provide doubts about the use of the rankings to judge the performance of universities. However, a good thing about the rankings is the creation of competitive approach to higher education and training which to a large extent enhances efficiency. Even with these identified flaws, the rankings should be an opportunity for African universities to review their performance in the global knowledge economy. This study has demonstrated that countries with high open access presence has the highest number of top 100 universities in Africa which is in line with the result of the correlation test. Evidently, therefore, African universities are 
likely to improve their global ranking with open access presence. Based on this, the study recommends as follow:

- African government need to develop the political will to provide the required supports for development of open access policy in their universities by creating sustainable ICT infrastructure, adequate funding of research and education and developing human capacity through training. This will in the long run attract foreign students, and improve the economy of African countries.

- University administrators in Africa should key into the open access initiative through the creation of repositories, self archiving of publications using Research Gate and publication in open access journals to provide wider visibility of their research outputs. Though, funding is a major challenge, creative administrator can source for funding through Public Private partnership (PPP). Universities are likely to attract more research grants through improved ranking.

- African university libraries are in the vintage position for the development of institutional repositories and therefore, it should be a priority project for all university libraries in Africa.

- The presence of institional repositories should be a key consideration of accreditation requirements of universities.

- All university regulatory bodies in Africa should develop Open Access framework in line with the recent Dakar Declaration on Open Access on Open Access Publishing in Africa and the Global South (CODESRIA, 2016).

\section{References}

Abbott, A., \& Leslie, D. (2004). Recent Trends in Higher Education Applications and Acceptances. Education Economics, 12(1), 67-86.

Bonaccorsi, A., \& Daraio, C. (2014). Beyond university rankings? Generating new indicators on European universities by linking data in open platforms. Technical Report n.12, Roma: Sapienza. ftp://ftp.repec.org/opt/ReDIF/RePEc/aeg/report/2014-12.pdf

Broecke, S. (2015). University rankings: do they matter in the UK? Education Economics, 23(2), 137 - 161. https://dx.doi.org/10.1080/09645292.2012.729328

Social Shaping of Digital Publishing: Exploring the Interplay between Culture and Technology. Proceeding of the $16^{\text {th }}$ International Conference on Electronic Publishing. Amsterdam: IOS Press, 12 - 23. http://doi.org/10.3233/978-1-61499-065-9-12

CODESRIA (2016). Dakar Declaration on Open Access on Open Access Publishing in Africa and the Global South. http://wiki.lib.sun.ac.za/images/5/50/Dakar-declaration-2016.pdf

Daraio, C., Bonaccorsi, A., \& Simar, L. (2015). Rankings and university performance: A conditional multidimensional approach. European Journal of Operational Research, 244(3), 918-930. 
Daraio, C., \& Bonaccorsi, A. (2016). Beyond university rankings? Generating new indicators on universities by linking data in open platforms. Journal of the Association of Information Science and Technology. Version of Record online: 28 MAR 2016.

https://doi.org/10.1002/asi.23679

Diodato, V. (1994). Dictionary of bibliometrics. New York: Haworth.

Ebrahim, N.A (2015). Strategies to enhance research visibility, impact and citations. http://works.bepress.com/aleebrahim/99

European University Association. (2012). Public funding observatory. http://www.eua.be/Libraries/governance-autonomy

funding/June_2012_report_FINAL.pdf?sfvrsn=0

Ezema, I.J. (2010a). Journal impact factors and the crisis of scholarly communication in Africa: the dilemma of Nigerian academics. Library Review, 59(5), 350-359. www.emeraldinsight.com/0024-2535.htm

Ezema, I.J. (2010b). Trends in Electronic Journal Publishing in Africa: An Analysis of African Journal Online (AJOL). Webology, 7(1).

Ezema, I.J (2011). Building open access institutional repositories for global visibility of Nigeria scholarly publication. Library Review, 60(6), 473-485.

https://doi.org/10.1108/00242531111147198

Ezema, I.J., \& Onyancha, O.B. (2016a). Status of Africa in the global open access directories: Implications for global visibility of African scholarly research. Fourth CODESRIA conference on electronic publishing: Open Access Movement and the Future of African Knowledge Economy, Dakar, Senegal.

http://www.codesria.org/spip.php?article2564\&lang=en

Ezema, I.J., \& Onyancha, O.B. (2016b). A Bibliometric analysis of health and medical journals: Issues in medical scholarly communication in Africa. Serials Review, 42(2), 116-128. http://doi.org/10.1080/00987913.2016.1182881

Ezema, I.J., \& Ugwu, C.I. (2013). Electronic theses and dissertations in Nigeria university libraries: status, challenges and strategies. The Electronic Library, 31(4), 493-507.

Fox, M., \& Hanlon, S.M (2015). Barriers to open access uptake for researchers in Africa. Online Information Review, 39(5), 698 - 716.

http://www.emeraldinsight.com/doi/pdfplus/10.1108/OIR-05-2015-0147

Hendrix, D. (2008). An analysis of bibliometric indicators, National Institutes of Health funding, and faculty size at Association of American Medical Colleges medical schools, 1997 - 2007. Journal of Medical Library Association, 96(4), 324-334.

Kraker, P, Jordan, K., \& Lex, E. (2015). Research Gate score: Good example of a bad metric. www.socialsciencespace.com/2015/.../researchgate-score-good-example-of-a-bad-met

Liu, N.C., \& Cheng, Y. (2005). The academic ranking of world universities. Higher Education in Europe, 30(2), 127-136. http://doi.org/10.1080/03797720500260116

Marginson, S. (2007). Global university ranking: Implication in general and for Australia. Journal of Higher Education Policy and Management, 29(2), 131-142.

http://doi.org/10.1080/13600800701351660

Marginson, S. (2009). Open sources knowledge and university rankings. Thesis Eleven, 96(1), 9-39. http://doi.org/10.1177/0725513608099118 
Marope, P.T.M., Wells, P.J., \& Hazelkorn, E. (Eds.). (2013). Rankings and accountability in higher education - uses and misuses. Paris: UNESCO Publishing.

Norris, M., Oppenheim, C., \& Rowland, F. (2008). The citation advantage of open-access articles. Journal of the American Society for Information Science and Technology, 59(12), 19631972.

Nwagwu, W.E (2013). Open access initiatives in Africa - structures, incentives and disincentives. The Journal of Academic Librarianship, 19(1), 3-10.

http://doi.org/10.1016/j.acalib.2012.11.024

Onyancha, O.B. (2011). Self-archiving by LIS schools in South Africa: practices, challenges and opportunities. ESARBICA Journal: Journal of the Eastern and Southern Africa Regional Branch of the International Council on Archives, 30, 66-84.

Onyancha, O.B. (2015). Social media and research: an assessment of the coverage of South African universities in ResearchGate, Web of Science and the Webometrics Ranking of World Universities. South African Journal of Libraries and Information Science, 81(1), 8-20. http://sajlis.journals.ac.za http://doi.org/10.7553/81-1-1540

Rauhvargers, A. (2013). Global university rankings and their impact: Report II. European University Association.

http://www.eua.be/Libraries/Publications_homepage_list/EUA_Global_University_Ranking s_and_Their_Impact_-_Report_II.sflb.ashx

Research Gate (2017). RG Scores: A new way to measure scientific reputation. https://www.researchgate.net/RGScore/FAQ

Rumsey, D.J. (2010). Statistical essentials for dummies. New York, John Wiley.

Shahjahan, R.A., Ramirez, G.B., \& Andreotti, V.O. (2017). Attempting to imagine the unimaginable: A decolonial reading of global university rankings. Comparative Educational Review, 16(S1).

https://www.journals.uchicago.edu/doi/abs/10.1086/690457

Thelwall, M., \& Kousha, K (2015). ResearchGate: Disseminating, Communicating, and Measuring Scholarship? Journal of the Association for Information Science and Technology, 66(5), 876-889. http://doi.org/10.1002/asi.23236

Times Higher Education (2015). World University Rankings 2014-2015. http://www.timeshighereducation.co.uk/world-university-rankings/2012-13/worldranking

Utulu, S.C.A., \& Bolarinwa, O. (2009). Open access initiatives adoption by Nigerian academics. Library Review, 58(9), 660-669. www.emeraldinsight.com/0024-2535.htm

Zaid Y.A., \& Okiki, O.C. (2014). Building Collaboration for an Institutional Repository in Africa: Transcending Barriers, Creating Opportunities. Journal of Interlibrary Loan, Document Delivery \& Electronic Reserve, 24(3-4), 103-111.

Sarabi, R.E., Abdekhoda, M., Dehnad, A., \& Khajouei, G. (2020). Environmental Literacy and Accountability of Undergraduate Students of Medical Sciences. Webology, 17(1), 191-201. 


\section{Appendix 1}

\section{African Universities and Higher Institutions Ranking (2015)}

This ranking is based on research publications and citations from the last five years (2010 to 2014) as well as visibility on the internet.

\begin{tabular}{|c|c|c|c|c|c|c|c|}
\hline Rank & Institution & Country & $\begin{array}{l}\text { Research } \\
\text { Publications } \\
\text { and } \\
\text { Citations }\end{array}$ & $\begin{array}{l}\text { Internet/Web } \\
\text { Presence }\end{array}$ & $\begin{array}{l}\text { RG } \\
\text { Scores }\end{array}$ & DOAR & $\begin{array}{l}\text { Total Influence } \\
\text { Factor }\end{array}$ \\
\hline 1 & $\begin{array}{l}\text { University of } \\
\text { Cape Town }\end{array}$ & South Africa & 40.89 & 4.13 & 29350.86 & 20272 & 45.02 \\
\hline 2 & $\begin{array}{l}\text { Cairo } \\
\text { University }\end{array}$ & Egypt & 39.75 & 3.68 & 25849.69 & 0 & 43.43 \\
\hline 3 & $\begin{array}{l}\text { University of } \\
\text { Pretoria }\end{array}$ & South Africa & 39.66 & 3.69 & 21631.05 & 48892 & 43.35 \\
\hline 4 & $\begin{array}{l}\text { University of } \\
\text { Nairobi }\end{array}$ & Kenya & 38.8 & 4.01 & 6212.20 & 78400 & 42.81 \\
\hline 5 & $\begin{array}{l}\text { University of } \\
\text { South Africa }\end{array}$ & South Africa & 37.72 & 4.6 & 5369.00 & 15617 & 42.32 \\
\hline 6 & $\begin{array}{l}\text { University of } \\
\text { the } \\
\text { Witwatersrand }\end{array}$ & South Africa & 39.07 & 3.14 & 22383.30 & 13256 & 42.2 \\
\hline 7 & $\begin{array}{l}\text { Stellenbosch } \\
\text { University }\end{array}$ & South Africa & 39.32 & 2.83 & 22407.18 & 60480 & 42.16 \\
\hline 8 & $\begin{array}{l}\text { University of } \\
\text { Ibadan }\end{array}$ & Nigeria & 38.45 & 2.77 & 8304.70 & 0 & 41.22 \\
\hline 9 & $\begin{array}{l}\text { University of } \\
\text { Kwazulu } \\
\text { Natal }\end{array}$ & South Africa & 38.36 & 2.77 & 19057.93 & 11779 & 41.13 \\
\hline 10 & $\begin{array}{l}\text { Ain Shams } \\
\text { University }\end{array}$ & Egypt & 37.54 & 3.01 & 15879.60 & 0 & 40.54 \\
\hline 11 & $\begin{array}{l}\text { University of } \\
\text { Johannesburg }\end{array}$ & South Africa & 36.97 & 3.09 & 7651.60 & 18659 & 40.05 \\
\hline 12 & $\begin{array}{l}\text { Makerere } \\
\text { University }\end{array}$ & Uganda & 36.67 & 3.35 & 8867.51 & 513 & 40.03 \\
\hline 13 & $\begin{array}{l}\text { University of } \\
\text { Nigeria }\end{array}$ & Nigeria & 35.98 & 3.98 & 8207.35 & 25667 & 39.96 \\
\hline 14 & $\begin{array}{l}\text { University of } \\
\text { Ghana }\end{array}$ & Ghana & 33.95 & 3.88 & 6063.59 & 6795 & 37.83 \\
\hline 15 & $\begin{array}{l}\text { Addis Ababa } \\
\text { University }\end{array}$ & Ethiopia & 33.49 & 2.64 & 5207.84 & 9098 & 36.13 \\
\hline 16 & $\begin{array}{l}\text { Rhodes } \\
\text { University }\end{array}$ & South Africa & 33.14 & 2.71 & 5067.37 & 4096 & 35.85 \\
\hline 17 & $\begin{array}{l}\text { Alexandria } \\
\text { University }\end{array}$ & Egypt & 32.9 & 2.72 & 12019.22 & 301647 & 35.62 \\
\hline 18 & $\begin{array}{l}\text { Ahmadu Bello } \\
\text { University }\end{array}$ & Nigeria & 32.9 & 2.66 & 3366.49 & \multirow{2}{*}{$\begin{array}{l}14368 \\
2595\end{array}$} & 35.57 \\
\hline 19 & $\begin{array}{l}\text { University of } \\
\text { the Western } \\
\text { Cape }\end{array}$ & South Africa & 31.8 & 3.02 & 6563.76 & & 34.82 \\
\hline
\end{tabular}


Webology, Volume 18, Number 2, December, 2021

\begin{tabular}{|c|c|c|c|c|c|c|c|}
\hline 20 & $\begin{array}{l}\text { University of } \\
\text { Lagos }\end{array}$ & Nigeria & 31.8 & 2.68 & 4223.08 & 619 & 34.48 \\
\hline 21 & $\begin{array}{l}\text { Al-Azhar } \\
\text { University }\end{array}$ & Egypt & 31.67 & 2.71 & 4859.71 & 0 & 34.38 \\
\hline 22 & $\begin{array}{l}\text { University of } \\
\text { the Free State }\end{array}$ & South Africa & 31.03 & 3.03 & 7201.23 & 4476 & 34.06 \\
\hline 23 & $\begin{array}{l}\text { Mansoura } \\
\text { University }\end{array}$ & Egypt & 31.23 & 2.65 & 13232.17 & 0 & 33.88 \\
\hline 24 & $\begin{array}{l}\text { Obafemi } \\
\text { Awolowo } \\
\text { University }\end{array}$ & Nigeria & 31.15 & 2.71 & 5668.80 & 0 & 33.85 \\
\hline 25 & $\begin{array}{l}\text { American } \\
\text { University in } \\
\text { Cairo }\end{array}$ & Egypt & 30.92 & 2.72 & 2637.83 & 16491 & 33.64 \\
\hline 26 & $\begin{array}{l}\text { North West } \\
\text { University }\end{array}$ & South Africa & 30.7 & 2.54 & 9160.44 & 17575 & 33.24 \\
\hline 27 & $\begin{array}{l}\text { University of } \\
\text { Benin }\end{array}$ & Nigeria & 30.29 & 2.67 & 2490.49 & 0 & 32.96 \\
\hline 28 & $\begin{array}{l}\text { Kenyatta } \\
\text { University }\end{array}$ & Kenya & 29.37 & 2.69 & $' 1928.54$ & 12884 & 32.05 \\
\hline Rank & Institution & Country & $\begin{array}{l}\text { Research } \\
\text { Publications } \\
\text { and } \\
\text { Citations }\end{array}$ & $\begin{array}{l}\text { Internet/Web } \\
\text { Presence }\end{array}$ & $\begin{array}{l}\text { RG } \\
\text { Scores }\end{array}$ & DOAR & $\begin{array}{l}\text { Total Influence } \\
\text { Factor }\end{array}$ \\
\hline 29 & $\begin{array}{l}\text { Kwame } \\
\text { Nkrumah } \\
\text { University of } \\
\text { Science and } \\
\text { Technology }\end{array}$ & Ghana & 28.97 & 2.61 & 3957.97 & 5916 & 31.58 \\
\hline 30 & $\begin{array}{l}\text { Zagazig } \\
\text { University }\end{array}$ & Egypt & 28.95 & 2.61 & 7427.78 & 0 & 31.56 \\
\hline 31 & $\begin{array}{l}\text { University of } \\
\text { Ilorin }\end{array}$ & Nigeria & 28.62 & 2.65 & 3240.05 & 78 & 31.27 \\
\hline 32 & $\begin{array}{l}\text { Assiut } \\
\text { University }\end{array}$ & Egypt & 28.18 & 2.57 & 9248.64 & 0 & 30.74 \\
\hline 33 & $\begin{array}{l}\text { Universite } \\
\text { d'Alger }\end{array}$ & Algeria & 27.06 & 2.56 & 539.04 & 12286 & 29.63 \\
\hline 34 & $\begin{array}{l}\text { University of } \\
\text { Khartoum }\end{array}$ & Sudan & 27.01 & 2.57 & 3524.35 & 16922 & 29.58 \\
\hline 35 & $\begin{array}{l}\text { University of } \\
\text { Zimbabwe }\end{array}$ & Zimbabwe & 26.84 & 2.62 & 3150.33 & 2251 & 29.47 \\
\hline 36 & $\begin{array}{l}\text { University of } \\
\text { Port Harcourt }\end{array}$ & Nigeria & 26.6 & 2.63 & 2405.67 & 0 & 29.24 \\
\hline 37 & $\begin{array}{l}\text { University of } \\
\text { Botswana }\end{array}$ & Botswana & 26.14 & 2.59 & 3408.04 & 1108 & 28.72 \\
\hline 38 & $\begin{array}{l}\text { University of } \\
\text { Zambia }\end{array}$ & Zambia & 25.81 & 2.58 & 2329.19 & 4104 & 28.39 \\
\hline 39 & $\begin{array}{l}\text { University of } \\
\text { Dar Es } \\
\text { Salaam }\end{array}$ & Tanzania & 25.47 & 2.63 & 2304.36 & 3575 & 28.1 \\
\hline 40 & $\begin{array}{l}\text { Nelson } \\
\text { Mandela } \\
\text { Metropolitan } \\
\text { University }\end{array}$ & South Africa & 25.08 & 2.61 & 4023.11 & 4396 & 27.69 \\
\hline
\end{tabular}


Webology, Volume 18, Number 2, December, 2021

\begin{tabular}{|c|c|c|c|c|c|c|c|}
\hline 41 & $\begin{array}{l}\text { Suez Canal } \\
\text { University }\end{array}$ & Egypt & 24.14 & 2.54 & 4878.13 & 0 & 26.69 \\
\hline 42 & $\begin{array}{l}\text { Nnamdi } \\
\text { Azikiwe } \\
\text { University }\end{array}$ & Nigeria & 23.94 & 2.59 & 2482.66 & 0 & 26.53 \\
\hline 43 & $\begin{array}{l}\text { University of } \\
\text { Calabar }\end{array}$ & Nigeria & 23.9 & 2.61 & 2008.49 & 0 & 26.52 \\
\hline 44 & $\begin{array}{l}\text { Universite } \\
\text { Mohammed V }\end{array}$ & Morocco & 23.68 & 2.56 & 1643.30 & 2571 & 26.24 \\
\hline 45 & $\begin{array}{l}\text { Tanta } \\
\text { University }\end{array}$ & Egypt & 23.64 & 2.56 & 9211.77 & 0 & 26.19 \\
\hline 46 & $\begin{array}{l}\text { Federal } \\
\text { University of } \\
\text { Technology } \\
\text { Minna }\end{array}$ & Nigeria & 23.59 & 2.59 & 1284.54 & 4414 & 26.19 \\
\hline 47 & $\begin{array}{l}\text { Moi } \\
\text { University }\end{array}$ & Kenya & 23.39 & 2.64 & 1076.70 & 928 & 26.03 \\
\hline 48 & $\begin{array}{l}\text { Tshwane } \\
\text { University of } \\
\text { Technology }\end{array}$ & South Africa & 23.32 & 2.69 & 3374.58 & 1710 & 26.01 \\
\hline 49 & $\begin{array}{l}\text { Federal } \\
\text { University of } \\
\text { Technology } \\
\text { Akure }\end{array}$ & Nigeria & 22.74 & 2.59 & 2229.54 & 2346 & 25.33 \\
\hline 50 & $\begin{array}{l}\text { University of } \\
\text { Limpopo }\end{array}$ & South Africa & 22.3 & 2.59 & 2284.46 & 938 & 24.89 \\
\hline 51 & $\begin{array}{l}\text { Helwan } \\
\text { University }\end{array}$ & Egypt & 21.67 & 2.6 & 3316.22 & 61 & 24.28 \\
\hline 52 & $\begin{array}{l}\text { University of } \\
\text { Fort Hare }\end{array}$ & South Africa & 21.67 & 2.56 & 1923.86 & 4395 & 24.23 \\
\hline 53 & $\begin{array}{l}\text { Covenant } \\
\text { University }\end{array}$ & Nigeria & 20.9 & 2.66 & 2042.08 & 5932 & 23.56 \\
\hline 54 & $\begin{array}{l}\text { Sudan } \\
\text { University of } \\
\text { Science and } \\
\text { Technology } \\
\end{array}$ & Sudan & 20.8 & 2.39 & 632.55 & 11782 & 23.19 \\
\hline 55 & $\begin{array}{l}\text { University of } \\
\text { Uyo }\end{array}$ & Nigeria & 20.42 & 2.57 & 1280.52 & 0 & 22.99 \\
\hline 56 & $\begin{array}{l}\text { University of } \\
\text { Cape Coast }\end{array}$ & Ghana & 20.26 & 2.61 & 1852.03 & 1390 & 22.87 \\
\hline Rank & Institution & Country & $\begin{array}{l}\text { Research } \\
\text { Publications } \\
\text { and } \\
\text { Citations } \\
\end{array}$ & $\begin{array}{l}\text { Internet/Web } \\
\text { Presence }\end{array}$ & $\begin{array}{l}\text { RG } \\
\text { Scores }\end{array}$ & DOAR & $\begin{array}{l}\text { Total Influence } \\
\text { Factor }\end{array}$ \\
\hline 57 & $\begin{array}{l}\text { Jomo } \\
\text { Kenyatta } \\
\text { University of } \\
\text { Agriculture } \\
\text { and } \\
\text { Technology }\end{array}$ & Kenya & 20.18 & 2.55 & 1807.34 & 1201 & 22.74 \\
\hline 58 & $\begin{array}{l}\text { Cape } \\
\text { Peninsula } \\
\text { University of } \\
\text { Technology }\end{array}$ & South Africa & 20.11 & 2.63 & 2773.40 & 3535 & 22.74 \\
\hline
\end{tabular}


Webology, Volume 18, Number 2, December, 2021

\begin{tabular}{|c|c|c|c|c|c|c|c|}
\hline 59 & $\begin{array}{l}\text { Lagos State } \\
\text { University }\end{array}$ & Nigeria & 19.97 & 2.66 & 1587.09 & 0 & 22.64 \\
\hline 60 & $\begin{array}{l}\text { University of } \\
\text { Namibia }\end{array}$ & Namibia & 19.97 & 2.56 & 1398.05 & 1162 & 22.53 \\
\hline 61 & $\begin{array}{l}\text { University of } \\
\text { Malawi }\end{array}$ & Malawi & 19.87 & 2.55 & 2010.40 & 0 & 22.42 \\
\hline 62 & $\begin{array}{l}\text { Egerton } \\
\text { University }\end{array}$ & Kenya & 19.79 & 2.57 & 1016.94 & 555 & 22.35 \\
\hline 63 & $\begin{array}{l}\text { Minia } \\
\text { University }\end{array}$ & Egypt & 19.71 & 2.36 & 4858.51 & 0 & 22.06 \\
\hline 64 & $\begin{array}{l}\text { University of } \\
\text { Jos }\end{array}$ & Nigeria & 19.41 & 2.64 & 1472.13 & 1199 & 22.04 \\
\hline 65 & $\begin{array}{l}\text { Ladoke } \\
\text { Akintola } \\
\text { University of } \\
\text { Technology }\end{array}$ & Nigeria & 19.46 & 2.57 & 2218.03 & 0 & 22.03 \\
\hline 66 & $\begin{array}{l}\text { University of } \\
\text { Maiduguri }\end{array}$ & Nigeria & 19.27 & 2.59 & 1225.93 & 0 & 21.85 \\
\hline 67 & $\begin{array}{l}\text { Benha } \\
\text { University }\end{array}$ & Egypt & 19.38 & 2.46 & 5682.82 & 0 & 21.83 \\
\hline 68 & $\begin{array}{l}\text { Bayero } \\
\text { University }\end{array}$ & Nigeria & 19.16 & 2.59 & 1161.94 & 0 & 21.75 \\
\hline 69 & $\begin{array}{l}\text { Delta State } \\
\text { University }\end{array}$ & Nigeria & 18.81 & 2.67 & 505.95 & 0 & 21.48 \\
\hline 70 & $\begin{array}{l}\text { Universite } \\
\text { Cheikh Anta } \\
\text { Diop }\end{array}$ & Senegal & 18.76 & 2.57 & 4113.38 & 321 & 21.33 \\
\hline 71 & $\begin{array}{l}\text { Federal } \\
\text { University of } \\
\text { Technology } \\
\text { Owerri }\end{array}$ & Nigeria & 18.7 & 2.59 & 888.56 & 0 & 21.29 \\
\hline 72 & $\begin{array}{l}\text { Jimma } \\
\text { University }\end{array}$ & Ethiopia & 17.98 & 2.51 & 2363.84 & 0 & 20.5 \\
\hline 73 & $\begin{array}{l}\text { Universite } \\
\text { Abou Bekr } \\
\text { Belkaid } \\
\text { Tlemcen }\end{array}$ & Algeria & 17.86 & 2.07 & 2716.35 & 7783 & 19.93 \\
\hline 74 & $\begin{array}{l}\text { Sokoine } \\
\text { University of } \\
\text { Agriculture }\end{array}$ & Tanzania & 17.29 & 2.54 & 2655.29 & 19.83 & \\
\hline 75 & $\begin{array}{l}\text { Olabisi } \\
\text { Onabanjo } \\
\text { University }\end{array}$ & Nigeria & 17.22 & 2.58 & 605.58 & 0 & 19.81 \\
\hline 76 & $\begin{array}{l}\text { Universite de } \\
\text { la Reunion }\end{array}$ & Reunion & 16.9 & 2.5 & 3757.36 & 0 & 19.4 \\
\hline 77 & $\begin{array}{l}\text { Universite } \\
\text { Kasdi Merbah }\end{array}$ & Algeria & 17.29 & 1.94 & 778.89 & 0 & 19.23 \\
\hline 78 & $\begin{array}{l}\text { Universite de } \\
\text { Yaounde }\end{array}$ & Cameroon & 17.26 & 1.92 & 5574.45 & 0 & 19.18 \\
\hline 79 & $\begin{array}{l}\text { University of } \\
\text { Venda }\end{array}$ & South Africa & 16.42 & 2.55 & 1286.87 & 0 & 18.97 \\
\hline 80 & $\begin{array}{l}\text { Federal } \\
\text { University of } \\
\text { Agriculture }\end{array}$ & Nigeria & 16.46 & 2.33 & 66.03 & 0 & 18.79 \\
\hline
\end{tabular}


Webology, Volume 18, Number 2, December, 2021

\begin{tabular}{|c|c|c|c|c|c|c|c|}
\hline 81 & $\begin{array}{l}\text { Universite de } \\
\text { Tunis El } \\
\text { Manar }\end{array}$ & Tunisia & 16.35 & 2.32 & 7702.17 & 692 & 18.67 \\
\hline 82 & $\begin{array}{l}\text { University of } \\
\text { Zululand }\end{array}$ & South Africa & 15.75 & 2.57 & 873.13 & 1344 & 18.32 \\
\hline 83 & $\begin{array}{l}\text { University of } \\
\text { Mauritius }\end{array}$ & Mauritius & 15.75 & 2.56 & 1799.88 & 0 & 18.31 \\
\hline 84 & $\begin{array}{l}\text { Universidade } \\
\text { Eduardo } \\
\text { Mondlane }\end{array}$ & Mozambique & 15.42 & 2.79 & 1296.72 & 3103 & 18.2 \\
\hline Rank & Institution & Country & $\begin{array}{l}\text { Research } \\
\text { Publications } \\
\text { and } \\
\text { Citations }\end{array}$ & $\begin{array}{l}\text { Internet/Web } \\
\text { Presence }\end{array}$ & $\begin{array}{l}\text { RG } \\
\text { Scores }\end{array}$ & DOAR & $\begin{array}{l}\text { Total Influence } \\
\text { Factor }\end{array}$ \\
\hline 85 & $\begin{array}{l}\text { University of } \\
\text { Abuja }\end{array}$ & Nigeria & 15.53 & 2.61 & 556.32 & 0 & 18.13 \\
\hline 86 & $\begin{array}{l}\text { Durban } \\
\text { University of } \\
\text { Technology }\end{array}$ & South Africa & 15.49 & 2.58 & 1910.84 & 1494 & 18.07 \\
\hline 87 & $\begin{array}{l}\text { Ebonyi State } \\
\text { University }\end{array}$ & Nigeria & 15.6 & 2.47 & 522.55 & 341 & 18.07 \\
\hline 88 & $\begin{array}{l}\text { Mekelle } \\
\text { University }\end{array}$ & Ethiopia & 15.71 & 2.28 & 1139.83 & 0 & 17.99 \\
\hline 89 & $\begin{array}{l}\text { Universite } \\
\text { Cadi Ayyad }\end{array}$ & Morocco & 15.38 & 2.54 & 7024.88 & 0 & 17.91 \\
\hline 90 & $\begin{array}{l}\text { Haramaya } \\
\text { University }\end{array}$ & Ethiopia & 15.6 & 2.3 & 734.49 & 0 & 17.9 \\
\hline 91 & $\begin{array}{l}\text { Michael } \\
\text { Okpara } \\
\text { University of } \\
\text { Agriculture }\end{array}$ & Nigeria & 15.6 & 2.21 & 702.47 & 0 & 17.81 \\
\hline 92 & $\begin{array}{l}\text { Usmanu } \\
\text { Danfodiyo } \\
\text { University }\end{array}$ & Nigeria & 15.49 & 2.22 & 970.87 & 0 & 17.71 \\
\hline 93 & $\begin{array}{l}\text { Universite } \\
\text { d'Abomey- } \\
\text { Calavi }\end{array}$ & Benin & 15.23 & 2.39 & 2576.71 & 0 & 17.62 \\
\hline 94 & $\begin{array}{l}\text { Universite de } \\
\text { Ouagadougou }\end{array}$ & $\begin{array}{l}\text { Burkina } \\
\text { Faso }\end{array}$ & 14.92 & 2.53 & 1807.80 & 0 & 17.45 \\
\hline 95 & $\begin{array}{l}\text { South Valley } \\
\text { University }\end{array}$ & Egypt & 15.49 & 1.92 & 1554.10 & 0 & 17.41 \\
\hline 96 & $\begin{array}{l}\text { Menoufia } \\
\text { University }\end{array}$ & Egypt & 15.42 & 1.95 & 3020.75 & 0 & 17.36 \\
\hline 97 & $\begin{array}{l}\text { Universite de } \\
\text { Sfax }\end{array}$ & Tunisia & 14.03 & 3.26 & 12161.81 & 0 & 17.29 \\
\hline 98 & $\begin{array}{l}\text { Fayoum } \\
\text { University }\end{array}$ & Egypt & 14.8 & 2.03 & 1861.45 & 0 & 16.83 \\
\hline 99 & $\begin{array}{l}\text { Rivers State } \\
\text { University of } \\
\text { Science and } \\
\text { Technology }\end{array}$ & Nigeria & 14.11 & 2.59 & 1694.58 & 0 & 16.7 \\
\hline \multirow[t]{2}{*}{100} & $\begin{array}{l}\text { Sohag } \\
\text { University }\end{array}$ & Egypt & 14.56 & 2.08 & 2348.39 & 0 & 16.64 \\
\hline & Total & & & & $480,798.82$ & & 794,031 \\
\hline
\end{tabular}

